\title{
ANALISIS PENDAPATAN USAHATANI KELAPA SAWIT PETANI PLASMA ANGGOTA KKPA (KREDIT KOPERASI PRIMER KEPADA ANGGOTA) DI PT. SARI ADITYA LOKA 1 KABUPATEN MERANGIN PROVINSI JAMBI
}

\section{THE ANALYSIS OF OIL PALM PLANTATION INCOME OF KKPA SCHEME PLASMA FARMERS IN PT. SARI ADITYA LOKA 1 MERANGIN REGENCY IN JAMBI PROVINCE}

\author{
Agustina Siregar ${ }^{1}$, Yusma Damayanti ${ }^{2}$ dan Elwamendri ${ }^{2}$ \\ ${ }^{1)}$ AlumniJurusan Agribisnis Program Studi Agribisnis Fakultas Pertanian Unja \\ ${ }^{2)}$ Staf Pengajar Jurusan Agribisnis Fakultas Pertanian Unja \\ Email :agustinasiregar11@yahoo.com
}

\begin{abstract}
ABSTRAK
Penelitian ini bertujuan untuk mengetahui penerapan kemitraan Kredit Koperasi Primer Kepada Anggota (KKPA) dan menganalisis pendapatan usahatani kelapa sawit petani plasma anggota KKPA di PT. Sari Aditya Loka 1.Penelitian ini telah dilaksanakan selama 5 bulan mulai bulan Januari sampai Juni 2015. Penelitian ini bertujuan untuk mengetahui penerapan pola kemitraan Kredit Koperasi Primer Anggota (KKPA) oleh PT. Sari Aditya Loka 1 pada petani plasma anggota KKPA di Kabupaten Merangin Provinsi Jambi, untuk menganalisis pendapatan usahatani kelapa sawit petani plasma anggota KKPA di PT. Sari Aditya Loka 1 Kabupaten Merangin Provinsi Jambi.Metode penelitian yang digunakan adalah survey. Data primer diperoleh melalui wawancara dengan responden dan data keuangan serta teknis lapangan PT. Sari Aditya Loka 1. Sedangkan data sekunder dikumpulkan dari instansi-instansi terkait seperti Badan Pusat Statistik Provinsi Jambi, Dinas Perkebunan Kota Jambi.Hasil penelitian menunjukkan bahwa sistem kemitraan yang dilakukan oleh PT. Sari Aditya Loka 1 adalah sistem KKPA dimana perusahaan inti dan petani dalam wadah koperasi untuk meningkatkan pendapatan para anggota melalui kredit jangka panjang dari bank. Pendapatan yang diterima oleh petani plasma anggota KKPA PT. Sari Aditya Loka 1 sebesar Rp. 1.545.255,26/petani/ha/bulan.Disarankan kepada Perusahaan agar melakukan pelatihan dan pembinaan pengurus KUD dan pengurus kelompok tani sangat diharapkan dalam kemitraan dan diharapkan adanya transparansi data pemotongan rutin dari pihak KUD terhadap petani plasma anggota KKPA agar petani mengetahui besaran hasil yang mereka terima setiap bulannya.
\end{abstract}

Kata Kunci : Kemitraan, Pendapatan, Petani Plasma anggota KKPA

ABSTRACT

The main goals of this research are 1) to know the application of the partnership pattern on Kredit Koperasi Primer Anggota (KKPA) by PT. Sari Aditya Loka 1 for Plasma farmers in Merangin regency in Jambi Province, 2) to analyze the income from KKPA scheme plasma farmers in PT. Sari Aditya Loka 1 Merangin regency in Jambi Province. It has been held for 5 months from January to June 2015. The primary data such as the financial data and also technical field as well in PT. Sari Aditya Loka 1were taken by doing some interviews with respondents. The secondary data wascollected from related institutions such as Centre of Jambi Provincial Statistics (BPS), Jambi Plantation Department.The results of this research showed that the system of partnerships which applied by PT. Sari Aditya Loka 1 is KKPA system in which farmers are guided directly by the company through Cooperation's Village Unit (KUD). Theincome received by plasma farmers in PT. Sari Aditya Loka 1 from 2014 to 2015 is Rp. 1.545.255,26/ Farmer / year. This was advised to the Company to improve the transportation and infrastructure facilities in order to expedite the oil palm process, especially in the transport of fresh fruit bunches (TBS), and also giving some trainings and guidiances to KUD staffs and farmer groups members which is hoped in partnership about the way of oil palm cultivation to the farmer group members so farmers could be active and independent in planting oil palm. Eventhough the age of old age group plantation income is already old, but it is still economicals.

Keywords: Partnership, Income, Plasma 


\section{PENDAHULUAN}

Pembangunan pertanian di era reformasi menempatkan petani sebagai subjek dalam rangka mencapai tujuan nasional. Tujuan pembangunan pertanian adalah memberdayakan petani menuju suatu masyarakat tani yang mandiri, maju, sejahtera dan berkeadilan. Pembangunan pertanian dapat dicapai melalui pembangunan pertanian yang berkelanjutan. Pembangunan pertanian yang berkelanjutan ditandai adanya kelangsungan produksi yang memberikan keuntungan, peningkatan produksi pertanian dan adanya kebebasan bagi petani untuk menentukan pilihan terbaik dalam berusaha tani (Kurniawan, 2004).

Kelapa sawit merupakan salah satu komoditi perkebunan. Kelapa sawit bukanlah tanaman asli di Indonesia dan baru ditanam secara komersil pada tahun 1911. Istilah kelapa mungkin dimaksud sebagai istilah umum untuk jenis palm. Meskipun demikian perkataan sawit sudah ada sejak lama. Beberapa tempat (desa di Pulau Jawa) sudah ada yang menggunakan nama "sawit" sebelum kelapa sawit masuk ke Indonesia pada tahun 1848 yang ditanam di Kebun Raya Bogor. Dalam Bahasa Jawa Kawi "sawit" artinya siedhakep, kalung. Nama lain dalam bahasa jawa adalah kelapa sewu dan dalam bahasa sunda sering disebut sebagai salak minyak atau kelapa ciung. (Sipayung dan Lubis, 1987)

Pembangunan Perkebunan Kelapa sawit telah dilakukan untuk perbaikan kesejahteraan petani kelapa sawit yaitu melalui kegiatan kemitraan. Kemitraan adalah suatu strategi bisnis yang dilakukan oleh dua pihak atau lebih dalam jangka waktu tertentu untuk meraih keuntungan bersama dengan prinsip saling membutuhkan dan saling membesarkan (Ernawati, 2011). Kemitraan dalam perkebunan kelapa sawit dikenal dalam beberapa pola yakni; Pola Kemitraan Perusahaan Inti Rakyat (PIR), Pola Kredit Koperasi Primer Kepada Anggota (KKPA) dan Pola Program Revitalisasi Perkebunan (PRP). Pola kemitraan adalah suatu bentuk kerja sama pembangunan dan pengembangan perkebunan dengan menggunakan perkebunan besar sebagai inti yang membimbing perkebunan rakyat disekitarnya sebagai plasma melalui lembaga koperasi dalam suatu sistem kerjasama yang saling menguntungkan, saling mengisi, utuh dan berkesinambungan. Sistem yang dilakukan dalam masing-masing pola memiliki berbagai macam bentuk misalnya; sistem hibah, sistem bagi hasil (Profit share) dan sistem kredit (Sunarko, 2009).

PT. Sari Aditya Loka 1 merupakan sebuah perusahaan yang bergerak di bidang perkebunan kelapa sawit di Kabupaten Merangin. Perusahaan ini memiliki pabrik pengolahan tandan buah segar (TBS) yang beroperasi selama 24 jam dengan pengolahan CPO sebanyak 70 ton/jam. Perusahaan ini juga memiliki kebun inti yang dikelola secara langsung oleh perusahaan serta kebun plasma yang dibina secara langsung oleh perusahaan melalui koperasi unit desa. PT. Sari Aditya Loka 1 merupakan perusahaan yang menjaga lingkungan sekitar dan hal ini dibuktikan dengan adanya sertifikat ISPO (Indonesian Sustainable Palm Oil) yang diberikan oleh pemerintah atas dedikasinya dalam menjaga keberlangsungan lingkungan.

Berdasarkan latar belakang seperti yang telah diuraikan diatas, maka yang menjadi pokok permasalahan penelitian ini adalah : (1) bagaimanakah gambaran penerapan kemitraan Kredit Koperasi Primer Anggota (KKPA) oleh PT. Sari Aditya Loka 1 pada petani plasma di Kabupaten Merangin Provinsi Jambi? ; dan (2) berapa tingkat pendapatan usahatani kelapa sawit kelompok usia tua petani plasma di PT. Sari Aditya Loka 1 Kabupaten Merangin Provinsi Jambi?

Tujuan dari penelitian ini adalah: (1) untuk mengetahui penerapan pola kemitraan Kredit Koperasi Primer Anggota (KKPA) oleh PT. Sari Aditya Loka 1 pada petani plasma di Kabupaten Merangin Provinsi Jambi ; (2) untuk menganalisis pendapatan usahatani kelapa sawit kelompok usia tua petani plasma di PT. Sari Aditya Loka 1 Kabupaten Merangin Provinsi Jambi. 


\section{METODE PENELITIAN}

Penelitian dilaksanakan di PT. Sari Aditya Loka 1 yang terletak di Kabupaten Merangin, Provinsi Jambi. Lokasi pengamatan intensif dilakukan pada ketiga Koperasi Unit Desa (KUD) terhadap petani plasma.Penelitian dilaksanakan selama 5 bulan mulai bulan Januari 2015 sampai dengan Juni 2015. Penelitian ini memerlukan alat tulis dan kuesioner untuk mengumpulkan data melalui survey. Data sekunder berupa data-data yang relevan dengan penelitian dari instansi-instansi terkait seperti Dinas Pertanian Kota Jambi, Badan Pusat Statistik. Data sekunder dijadikan pedoman untuk mengumpulkan data primer berupa struktur biaya dan penerimaan usahatani kelapa sawit petani plasma anggota KKPA. Data tersebut diperoleh melalui wawancara dengan responden petani plasma dan pengurus-pengurus Koperasi Unit Desa (KUD). Sampel responden petani ditetapkan secara purposive berdasarkan petani plasma aggota KKPA dengan jumlah responden petani adalah $15 \%$ dari populasi petani plasma PT. Sari Aditya Loka 1 sedangkan responden pengurus Koperasi Unit Desa ditetapkan sesuai ketiga KUD yang merupakan lokasi penelitian.

Struktur biaya usahatani diketahui melalui pengumpulam data jenis, volume dan harga input. kelapa sawit untuk menentukan total penerimaan usahatani kelapa sawit. Pendapatan petani adalah selisih total penerimaan dengan total biaya usahatani. Harga yang digunakan dalam analisis adalah harga yang berlaku pada saat penelitian berlangsung dan diasumsikan tetap

\section{HASIL DAN PEMBAHASAN}

\section{Gambaran Usahatani Kelapa Sawit}

Tanaman kelapa sawit yang diusahakan petani didaerah penelitian adalah varietas Tenera dari hasil persilangan Dura dan Psifera. Fisiografi wilayah dilokasi penelitian berdasarkan keadaan landform digolongkan kedalam 3 grup yaitu Kubah Gambut (Dome), Tektonik dan Alluvial. Grup kubah gambut terdiri dari landform rawa belakang.Status kepemilikan lahan usahatani kelapa sawit didaerah penelitian sudah menjadi hak milik sendiri. Pembukaan lahan yang dilakukan pada tahun 1987/1988 pada program pemerintah untuk masyarakat transmigrasi dimana setiap keluarga mendapatkan pembagian lahan dari pemerintah seluas 2,25 ha dimana 2 ha digunakan untuk perkebunan kelapa sawit dan 0,25 ha lagi digunakan untuk rumah dan pekarangan. Kemudian perusahaan PT. Sari Aditya Loka 1 mengelola kebun masyarakat secara serempak (melakukan penanaman secara serentak) dengan catatan bahwa hasil yang didapat oleh petani mengalami pembagian hasil hingga pembayaran (kredit) mereka lunas. Sekarang usia tanaman dilokasi penelitian adalah 24 tahun dan sudah seluruh kebun petani plasma lunas dengan artian tidak ada lagi pembagian hasil antara perusahaan dan petani hanya saja petani plasma PT. Sari Aditya Loka 1 tetap bekerjasama dengan perusahaan PT. Sari Aditya Loka 1 dan dibina secara lagsung oleh Koperasi Unit Desa (KUD) masing-masing daerah.

\section{Identitas Responden}

Berdasarkan hasil wawancara, maka diperoleh gambaran identitas terhadap 43 petani plasma responden dari 3 KUD sebagai perwakilan yaitu KUD Desa Bungo Antoi, KUD Pematang Kabau, dan KUD Gading Jaya. Identitas seseorang merupakan cerminan status sosial orang yang bersangkutan dimana mereka hidup bermasyarakat. Identitas responden dalam penelitian ini meliputi : nama, umur, pendidikan, luas lahan usahatani, jumlah anggota keluarga,lama berusahatani, dan status kepemilikan.

\section{Umur Responden}

Umur mempunyai kaitan yang erat dengan berbagai segi kehidupan petani dalam hal menjalankan kegiatan usahataninya. Tingkat umur dapat mempengaruhi terhadap kemampuan fisik 
petani dalam bekerja dan kemampuan dalam berfikir. Menurut Hernanto (1995), bahwa ada kecenderungan petani yang semakin tua, pertimbangan dan pengambilan keputusan lebih lama dibandingkan yang muda. Sebaliknya petani yang berusia lebih muda memiliki kemampuan bekerja yang lebih produktif dan lebih respon terhadap introduksi tekonologi baru.Umur petani sampel daerah penelitian baervariasi dengan batas umur terendah 25 tahun dan batas umur tertinggi 71 tahun (Tabel 1).

Tabel 1. Distribusi responden berdasarkan kelompok umur di daerah penelitian tahun 2015

\begin{tabular}{cccc}
\hline No & Umur (Tahun) & Frekuensi (Orang) & Persentase (\%) \\
\hline 1 & $45-49$ & 6 & 13,95 \\
2 & $50-54$ & 7 & 16,27 \\
3 & $55-59$ & 8 & 18,60 \\
4 & $60-64$ & 10 & 23,25 \\
5 & $65-70$ & 8 & 18,60 \\
6 & $71-75$ & 4 & 9,33 \\
\hline & & $\mathbf{4 3}$ & $\mathbf{1 0 0 , 0 0}$ \\
\hline
\end{tabular}

Tabel 1 memperlihatkan bahwa di daerah penelitian sebanyak 43 petani sampel petani plasma komoditi kelapa sawit banyak berada pada rentang usia 60-64 tahun yang berjumlah 10 orang atau 23,25 persen dari keseluruhan petani sampel, sedangkan jumlah petani paling sedikit berada pada rentang usia 71-75 tahun yaitu 4 orang atau sebesar 9,33 persen dari keseluruhan petani sampel. Data ini menunjukkan bahwa sebagian besar petani didaerah penelitian tergolong tidak produktif lagi.

\section{Pendidikan Responden}

Pendidikan merupakan proses menyampaikan ilmu, pengetahuan, keterampilan maupun sikap seseorang yang dilaksanakan secara terencana sehingga diperoleh perubahan-perubahan dalam meningkatkan taraf hidup. Tingkat pendidikan petani sangat berhubungan dengan perilaku dan pola pikir petani dalam mengembangkan usahataninya. Hernanto (1995) mengatakan bahwa tingkat pendidikan akan mempengaruhi cara berfikir, menerima dan mencoba hal baru. Begitu pula sebaliknya mereka yang berpendidikan rendah, mereka agak sulit untuk melaksanakan adopsi inovasi dengan cepat. Dalam penelitian ini, tingkat pendidikan petani diukur berdasarkan pendidikan formal yang pernah dilalui petani (Tabel 2)

Tabel 2. Distribusi responden berdasarkan tingkat pendidikan di daerah penelitian $\mathbf{t}$ 2015

\begin{tabular}{llcc}
\hline No & Tingkat Pendidikan & Frekuensi (Orang) & Persentase (\%) \\
\hline 1 & Tidak Tamat SD & 16 & 37,20 \\
2 & SD/Sederajat & 24 & 55,81 \\
3 & SLTP/Sederajat & 2 & 4,65 \\
4 & SLTA/Sederajat & 1 & 2,34 \\
\hline & Jumlah & $\mathbf{4 3}$ & $\mathbf{1 0 0 , 0 0}$ \\
\hline
\end{tabular}

Berdasarkan Tabel 2 diatas diketahui bahwa rata-rata tingkat pendidikan petani plasma yang ada di PT. Sari Aditya Loka 1 adalah SD yaitu sebanyak 24 orang atau 55,81 persen.

\section{Jumlah Anggota Keluarga}

Jumlah tanggungan keluarga adalah salah satu faktor ekonomi yang perlu diperhatikan dalam menentukan pendapatan dalam memenuhi kebutuhannya (Hasyim, 2006). Jumlah anggota 
keluarga dapat mempengaruhi petani dalam mengambil keputusan dalam mengelola usahataninya. Semakin besar jumlah anggota keluarga semakin besar pula kebutuhan yang harus dipenuhi. Bisa diasumsikan bahwa semakin banyak jumlah anggota keluarga maka semakin besar keinginan untuk mencapai kepuasan. Jumlah anggota keluarga yang dimaksud dalam penelitian ini adalah jumlah anggota keluarga yang terdiri dari suami, istri, anak dan anggota keluarga lainnya yang tinggal bersama dalam satu keluarga dan sekaligus menjadi tanggungan kepala keluarga (Tabel 3).

Tabel 3. Distribusi responden berdasarkan jumlah anggota rumah tangga di , penelitian tahun 2015

\begin{tabular}{cccc}
\hline No & Jumlah Anggota Keluarga & Frekuensi (KK) & Persentase (\%) \\
\hline 1 & 1 & 2 & 4,65 \\
2 & 2 & 5 & 11,52 \\
3 & 3 & 12 & 27,90 \\
4 & 4 & 13 & 30,23 \\
5 & 5 & 5 & 11,62 \\
6 & 6 & 4 & 9,30 \\
7 & 7 & 2 & 4,78 \\
\hline & Jumlah & $\mathbf{4 3}$ & $\mathbf{1 0 0 , 0 0}$ \\
\hline
\end{tabular}

Tabel 3 menunjukkan bahwa jumlah anggota keluarga di daerah penelitian relatif bervariasi, jumlah anggota keluarga petani sampel yang tertinggi adalah 4 orang atau sebesar 30,23 persen. Jumlah tanggungan keluarga akan mempengaruhi tingkat pendapatan yang diperolehnya. Jika jumlah tanggungan keluarga yang lebih besar tentu pemenuhan kebutuhan keluarga akan besar pula.

\section{Lama Berusahatani Kelapa Sawit}

Pengalaman seseorang akan dapat dijadikan tolak ukur untuk pengembangan kegiatan di masa mendatang, karena jika semakin lama bekerja seseorang diharapkan lebih baik dan sempurna dalam melaksanakan tugasnya. Dengan adanya pengalaman berusahatani yang cukup lama berarti petani akan mengubah cara dan kebiasaan yang kurang menguntungkan pada masa lalu dalam mengelola usahataninya. Pengalaman berusahatani yang dimaksud adalah pengalaman petani berusahatani kelapa sawit. Menurut Soekartawi (2002) bahwa pengalaman seseorang dalam berusahatani berpengaruh dalam menerima inovasi dari luar. Petani yang sudah lebih lama bertani akan lebih mudah menerapkan inovasi dari pada petani pemula.

Tabel 4 berikut.

Adapun pengalaman berusahatani petani sampel didaerah penelitian diuraikan pada

Tabel 4. Distribusi responden berdasarkan lama berusahatani kelapa sawit di di penelitian tahun 2015

\begin{tabular}{cccc}
\hline No & Lama Berusahatani (Tahun) & Frekuensi (Orang) & Persentase (\%) \\
\hline 1 & $23-25$ & 7 & 16,27 \\
2 & $26-28$ & 4 & 9,30 \\
3 & $29-31$ & 12 & 27,90 \\
4 & $32-34$ & 7 & 16,27 \\
5 & $35-37$ & 5 & 11,62 \\
6 & $38-40$ & 2 & 4,65 \\
7 & $41-45$ & 6 & 13,99 \\
\hline & Jumlah & $\mathbf{4 3}$ & $\mathbf{1 0 0 , 0 0}$ \\
\hline
\end{tabular}

Tabel 4 menunjukkan bahwa pengalaman petani plasma dalam berusahatani kelapa sawit di 
PT. Sari Aditya Loka 1. Hasil penelitian menjelaskan bahwa pengalaman petani dalam berusahatani kelapa sawit cukup lama atau berpengalaman tertinggi yaitu selama 29-31 tahun atau 27,90 persen dari jumlah keseluruhan petani sampel, namun meskipun begitu petani plasma di PT. Sari Aditya Loka 1 masih membutuhkan bimbingan dari pihak perusahaan baik secara teknis maupun non-teknis. Hal ini sangat penting untuk membantu petani dalam mengembangkan usahataninya dan juga dalam penyelesaian kendala-kendala dalam berusahatani.

\section{Penerapan Kemitraan Pada PT. Sari Aditya Loka 1}

Sistem baru terjadi pada pola kemitraan KKPA yang bertujuan untuk meningkatkan daya guna lahan petani peserta dalam usaha meningkatkan pendapatan dan kesejahteraan para anggota melalui kredit jangka panjang dari bank dan dibentuklah Koperasi Unit Desa (KUD) selaku pemegang kredit petani namun perusahaan selaku pembina petani maupun KUD. Sistem pencucuran dana yang diberikan kepada petani melalui Bank BNI memiliki kriteria dimana KUD yang akan dipinjamkan oleh dana oleh Bank BNI harus dianalisa mengenai sistem kerja KUD tersebut, jika KUD tersebut dinyatakan aktif dan layak maka Bank BNI akan memberikan pinjaman kepada petani plasma di KUD tersebut sebagai peminjaman kredit.

Sistem kemitraan KKPA di PT. Sari Aditya Loka 1 dimulai pada tahun 2004. Sistem yang berjalan adalah petani dibina secara langsung oleh perusahaan melalui KUD. Setelah adanya peminjaman dana oleh koperasi kepada petani, dimulailah sistem pemotongan dengan bagi hasil pola $70 \%: 30 \%$ dimana $70 \%$ diserahkan kepada petani dan $30 \%$ diserahkan kepada koperasi untuk pembayaran cicilan kredit. Hasil yang diterima murni adalah hasil penjualan produksi TBS petani plasma anggota KKPA kepada PT. Sari Aditya Loka 1.

Sesuai peraturan yang berlaku yang tertera pada SPK (Surat Peranjian Kemitraan), pola kemitraan KKPA mengharuskan kebun petani plasma dikelola oleh perusahaan, namun yang terjadi di PT. Sari Aditya Loka 1 bahwa anggota KUD selaku petani plasma anggota KKPA meminta secara lansung kepada ketua KUD dan perusahaan agar memberikan kebun petani dikelola oleh petani sendiri. Maka pola KKPA yang diterapkan oleh PT. Sari Aditya Loka 1 merupakan pola kemitraan KKPA yang tidak murni.

Pola kemitraan sekarang yang diterapkan di perusahaan lainnya di Provinsi Jambi berbeda dengan pola kemitraan yang diterapkan PT. Sari Aditya Loka 1. PT. Sari Aditya Loka 1 adalah perusahaan yang telah ada sejak program transmigrasi. Pola kemitraan pada saat transmigrasi sangat berbeda dengan pola kemitraan sekarang. Pada saat transmigrasi, pola kemitraan yang terjadi memiliki prioritas dari pusat yaitu untuk pemerataan pendapatan. Maka kemitraan yang terjadi antara petani plasma dengan PT. Sari Aditya Loka 1 sangat memfokuskan untuk kesejahteraan petani. Perjanjian yang terjadi antara petani dengan perusahaan dalam bentuk SPK (Surat Perjanjian Kemitraan) tidak ada tertulis namun tersirat dengan jelas, disamping itu data yang menunjang mengenai perjanjian antara perusahaan dan petani tidak tersedia di perusahaan.

\section{Penerimaan Usahatani Kelapa Sawit}

Tanaman kelapa sawit adalah jenis tanaman jangka panjang dan pada umumnya tanaman kelapa sawit yang tumbuh dengan baik dan subur sudah dapat menghasilkan buah serta siap dipanen pada umur sekitar 3,5 tahun. Umur tanaman di lokasi penelitian mayoritas berumur 24 tahun dikarenakan lahan masyarakat dilokasi penelitian mengalami pembukaan awal pada tahun 1987 dan akan direncanakan pada tahun 2016 diadakan Replanting bagi kebun-kebun plasma PT. Sari Aditya Loka 1.

Produksi kelapa sawit yang dimaksud dalam penelitian ini adalah produksi fisik berupa Tandan Buah Sawit (TBS) dalam bentuk ton atau kilogram yang diperoleh petani dari hasil panen kelapa sawitnya. TBS yang dipanen adalah TBS yang telah matang sesuai dengan kriteria tingkat kematangan buah kelapa sawit. Tanaman kelapa sawit di daerah penelitian dipanen sebanyak 2 kali hingga 3 kali dalam sebulan. Pada penelitian ini, jumlah produksi tanaman kelapa sawit petani 
plasma diambil dalam satuan $\mathrm{Kg} / \mathrm{ha} /$ bulan. Untuk mengetahui distribusi produksi usahatani kelapa sawit petani plasma dapat dilihat pada grafik dibawah ini. Dari grafik dibawah menunjukkan bahwa produksi tertinggi didaerah penelitian berada pada $12.100 \mathrm{Kg} / \mathrm{ha} / \mathrm{bulan}$ dengan rata-rata produksi $3.086,05 \mathrm{Kg} / \mathrm{ha} / \mathrm{bulan}$.

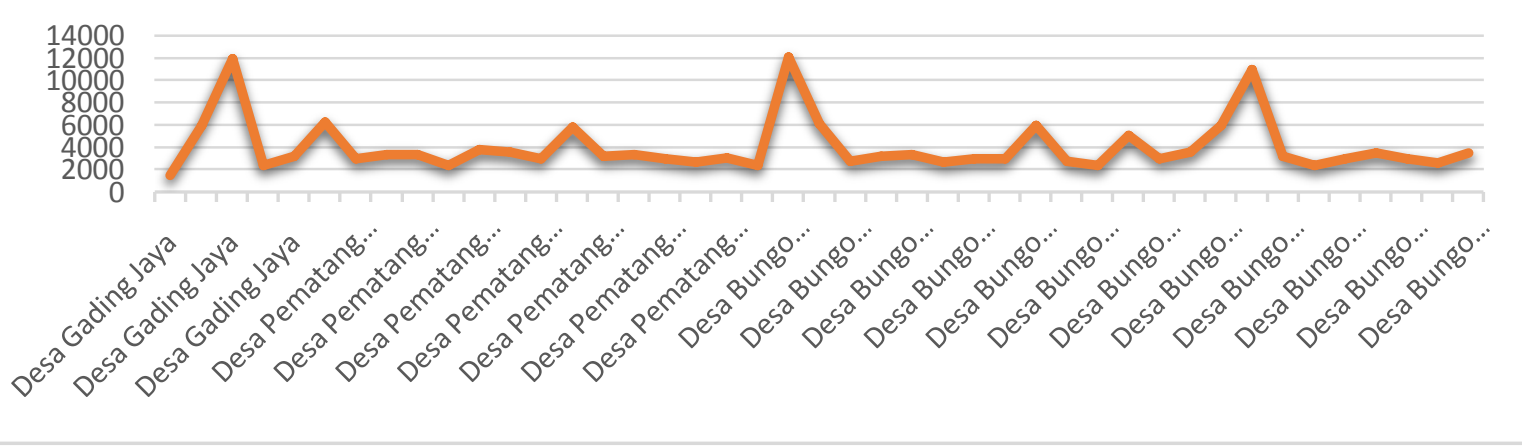

Penerimaan adalah nilai yang diperoleh dari hasil perkalian seluruh hasil produksi dengan harga jual produksi. Harga jual produksi di daerah penelitian sering mengalami fluktuasi pada waktuwaktu tertentu.Harga jual TBS sebesar Rp. 1.694 per kg (dengan asumsi harga konstan pada saat penelitian) dan untuk mengetahui penerimaan usahatani kelapa sawit petani plasma di daerah penelitian dapat dilihat pada Tabel 5 berikut ini.

Tabel 5. Rata-rata penerimaan usahatani kelapa sawit petani plasma di daerah penelitian tahun 2015

\begin{tabular}{cll}
\hline No & Penerimaan Petani Plasma & Rupiah/Bulan \\
\hline 1 & Per Petani & 5.227 .763 \\
2 & Per Ha & $1.963 .264,71$ \\
\hline
\end{tabular}

Berdasarkan penelitian yang dilakukan oleh Wijayanti (2012) mengenai analisis pendapatan usahatani kelapa sawit di Desa Makmur Jaya Kecamatan Kongbeng Kabupaten Kutai Timur menyimpulkan bahwa penerimaan usahatani kelapa sawit di desa makmur adalah sebesar Rp $56.956 .448,72 /$ responden. Ternyata dari ketiga penelitian diatas, penerimaan yang dilakukan oleh ketiga peneliti tidak jauh berbeda.

\section{Biaya-Biaya Usahatani Kelapa Sawit}

Biaya usahatani kelapa sawit diartikan sebagai besarnya biaya yang dikeluarkan oleh petani sampel di daerah penelitian dalam mengelola tanaman-tanaman kelapa sawit miliknya, meliputi: biaya tenaga kerja, biaya pupuk, biaya obat-obatan dan biaya koperasi. Biaya usahatani digolongkan menjadi dua yaitu biaya tetap dan biaya variabel.

\section{Total Biaya Usahatani Kelapa Sawit Petani Plasma}

Total biaya adalah keseluruhan biaya yang dikeluarkan dalam usahatani kelapa sawit atau total biaya adalah penjumlahan biaya tetap dan biaya tidak tetap (Soekartawi, 2002). Secara keseluruhan biaya usahatani kelapa sawit yang harus dikeluarkan oleh petani plasma menjadi biaya total dalam perawatan kebun kelapa sawit. Jenis biaya yang dikeluarkan tertera pada Tabel 6. 
Tabel 6. Komponen rata-rata biaya produksi usahatani kelapa sawit petani plasma di PT. Sari aditya loka 1, tahun 2015

\begin{tabular}{clrr}
\hline \multirow{2}{*}{ No } & \multicolumn{1}{c}{ Jenis Biaya } & Biaya (Rp/Petani) & \multicolumn{1}{c}{ Biaya (Rp/ha) } \\
\hline 1 & Rata-Rata Biaya Pemotongan KUD & $5.293 .953,49$ & $1.990 .208,07$ \\
2 & Rata-Rata Biaya Penyusutan & $188.911,68$ & $71.019,42$ \\
3 & Rata-Rata Upah Tenaga Kerja & 3.024 .000 & $1.136 .842,1$ \\
4 & Rata-Rata Biaya Pupuk & $3.883 .139,53$ & $1.459 .826,89$ \\
5 & Rata-Rata Obat-Obatan & $1.018 .604,65$ & $382.934,07$ \\
\hline & Rata-Rata Biaya Keseluruhan (Rp/Tahun) & $\mathbf{1 3 . 4 0 8 . 6 0 9 , 3 5}$ & $\mathbf{5 . 0 4 0 . 8 3 0 , 5 5}$ \\
\hline & Rata-Rata Biaya Keseluruhan (Rp/Bulan) & $\mathbf{1 . 1 1 7 . 3 8 4 , 1 1}$ & $\mathbf{4 2 0 . 0 6 9 , 2 1}$ \\
\hline
\end{tabular}

Berdasarkan penelitian yang dilakukan oleh Noris (2015) mengenai analisis pendapatan usahatani kentang di kecamatan jangkat kabupaten merangin menyimpulkan bahwa biaya total pembiayaan secara ekonomi diperhitungkan sebesar Rp. 39.739.504 per hektar. Sedangkan penelitian yang dilakukan oleh Wijayanti (2012) mengenai analisis pendapatan usahatani kelapa sawit di Desa Makmur Jaya Kecamatan Kongbeng Kabupaten Kutai Timur menyimpulkan bahwa biaya total pembiayaan secara ekonomi diperhitungkan rata-rata $\mathrm{Rp} 4.126 .082,93$ responden/responden. $\mathrm{Hal}$ ini sangat berbanding jauh dengan total biaya pada tabel diatas dikarenakan biaya yang dikeluarkan oleh petani responden di daerah penelitian lebih kecil karena petani responden berasumsi bahwa tanaman usia tua sudah tidak perlu di rawat secara rutin disamping keterbatasan modal juga petani responden di daerah penelitian akan segera melakukan Replanting.

\section{Pendapatan Usahatani Kelapa Sawit Petani Plasma}

Keberhasilan dari usahatani dapat dilihat dari pendapatan usahatani yang diperoleh petani. Pendapatan usahatani kelapa sawit petani plasma adalah penerimaan dari KUD dikurangi dengan biaya-biaya produksi yang dikorbankan/diperhitungkan di tingkat petani plasma, atau dengan kata lain pendapatan bersih petani adalah penerimaan dari tingkat KUD dikurangi dengan biaya-biaya yang dikorbankan petani dan tidak ditanggung dalam biaya-biaya yang telah dispekati kemitraan. Biaya-biaya yang dikorbankan petani meliputi; biaya penyusutan alat, biaya tenaga kerja dalam keluarga dan biaya obat-obatan (Tabel 7).

Tabel 7. Pendapatan usahatani kelapa sawit petani peserta kemitraan di daerah penelitian 2015

\begin{tabular}{lr}
\hline Total Penerimaan Rp/petani/bulan & 5.227 .763 \\
Total Biaya Rp/petani/bulan & $1.117 .384,11$ \\
Pendapatan Rp/petani/bulan & $\mathbf{4 . 1 1 0 . 3 7 9}$ \\
\hline Pendapatan Rata-Rata Rp/ha/bulan & $\mathbf{1 . 5 4 5 . 2 5 5 , 2 6}$ \\
\hline
\end{tabular}

Berdasarkan Tabel 7 dapat dilihat bahwa total penerimaan petani plasma PT. Sari Aditya Loka 1 sebesar Rp. 5.227.763/petani/bulan sehingga pendapatan bersih pada tingkat petani adalah sebesar Rp. 1.545.255,26/petani/ha/bulan.Berdasarkan penelitian yang dilakukan oleh Hermansyah (2011) mengenai analisis pendapatan usahatani kelapa sawit pasca umur ekonomis (27 Tahun) pada perkebunan sawit inti rakyat di kecamatan luhak nan duo kabupaten pasaman barat menyimpulkan bahwa total pendapatan yang diterima oleh petani inti sawit adalah sebesar Rp. 33. 409.319,27/petani/ha. Ternyata dari kedua perbandingan pendapatan diatas tidak jauh beda bahwasanya tanaman kelapa sawit kelompok usia tua maupun pasca ekonomis (27 Tahun) masih ekonomis. 


\section{KESIMPULAN}

Dari hasil penelitian yang telah dilaksanakan, maka dapat ditarik kesimpulan sebagai berikut:

1. Penerapan kemitraan yang dilakukan oleh PT. Sari Aditya Loka petani dibina secara langsung oleh perusahaan melalui KUD dalam mengelola, memanajemen kebun petani plasma anggota KKPA. Sistem pemotongan bagi hasil tidak diterapkan lagi di PT. Sari Aditya Loka 1 dikarenakan semua kebun petani plasma anggota KKPA telah lunas dan sekarang seluruh kebun petani plasma anggota KKPA telah dikelola oleh petani sendiri namun hasil TBS yang diperoleh tetap dijual keperusahaan sehingga kemitraan tetap terjadi dengan baik.

2. Pendapatan usahatani kelapa sawit petani plasma yang diperhitungkan ditingkat petani adalah sebesar Rp. 69.691.902,04/petani/tahun

\section{UCAPAN TERIMA KASIH}

Pada kesempatan kali ini penulis menyampaikan ucapan terima kasih kepada Dekan Fakultas Pertanian Universitas Jambi dan Ketua Program Studi Agribisnis Fakultas Pertanian Universitas Jambi yang telah memfasilitasi pelaksanaan penelitian ini, Selain itu ucapan terimakasih juga kepada Kepala Administrasi (ADM), Kepala Kebun Plasma, Ketua Koperasi Unit Desa (KUD), serta petani-petani plasma PT. Sari Aditya Loka 1 yang sangat luar biasa dimana telah memfasilitasi pelaksanaan penelitian di lapangan dan memberikan dukungan yang sangat baik bagi peneliti.

\section{DAFTAR PUSTAKA}

Hermansyah. 2011. Analisis Pendapatan Usahatani Kelapa Sawit Pasca Umur Ekonomis (27 Tahun) pada Perkebunan Sawit Inti Rakyat di Kecamatan Luhak Nan Duo Kabupaten Pasaman Barat. Jurnal Penelitian Fakultas Pertanian Universitas Andalas.

Hernanto, Fadholi. 1994. IImu Usahatani. Penebar Swadaya. Jakarta

Indonesian Palm Oil Statistics. 2013. Statistik Kelapa Sawit Indonesia 2012. Badan Pusat Statistik. Jakarta.

Lubis, Adlin. 2008. Kelapa Sawit (Elaeis guineensis Jaca.) di Indonesia. Pusat Penelitian Kelapa Sawit. Medan

Melanita, Yustina. 2015. Analisis Usahatani dan Faktor-Faktor yang Berhubungan dengan Produksi Kopi Robusta di Kecamatan Lembah Masurai Kabupaten Merangin. Fakultas Pertanian. Universitas Jambi.

Siburian, Altur Manaek. 2013. Analisis Pendapatan Usahatani Kelapa Sawit Rakyat (Swadaya Murni) dan Faktor yang Mempengaruhinya di Kecamatan Sekernan Kabupaten Muaro Jambi. Jurnal Penelitian Program Studi Agribisnis Fakultas Pertanian Universitas Jambi.

Sipayung dan Lubis. 1987. Sejarah Kelapa Sawit Indonesia. Nuhamedika. Yogyakarta

Soekartawi. 2002. Analisis Usahatani. Penerbit Universitas Indonesia. Jakarta

Tamba, Rio S. 2015. Kajian Pendapatan Usahatani Kelapa Sawit Petani Peserta Kemitraan Revitalisasi pada PT. Brahma Bina Bakti di Kecamatan Sekernan Kabupaten Muaro Jambi. Skripsi Fakultas Pertanian Universitas Jambi. Jambi.

Tim Bina Karya Tani. 2009. Budidaya Tanaman: Pedoman Bertanam Kelapa Sawit. Yrama Widya. Bandung 
Wijayanti, Tetty. 2012. Analisis Pendapatan Usahatani Kelapa Sawit (Elaeis guineensis Jacq.) di Desa Makmur Jaya Kecamatan Kongbemg Kabupaten Kutai Timur. Jurnal Media Sains, ISSN 20853548. Fakultas Pertanian Universitas Mulawarman. 